\title{
INDUSTRIAL ENGINEERING : ROOTING FOR ROOTS, HANKERING FOR HEROES
}

\author{
P.S. Kruger \\ Department of Industrial and Systems Engineering \\ University of Pretoria \\ paul.kruger@eng.up.ac.za
}

\begin{abstract}
The "roots" of Industrial Engineering are certainly extensive, diverse and deep. Similarly, there are numerous historical "heroes" that made significant contributions to the development of the Industrial Engineering discipline. For the sake of argument, this article will assume that Industrial Engineering has at least two identifiable main roots, namely Determinism and Stochastism. The article attempts to trace the early history ${ }^{1}$ of the stochastic root which is very closely linked to the history of probability and statistics and hence games of chance, gambling and divinity. Therefore, the life and times, contributions and personalities of some of the heroes and villains, champions and sad cases of the stochastic world, will be briefly discussed in a somewhat light-hearted, but not necessarily flippant, manner.
\end{abstract}

\section{OPSOMMING}

Die "wortel en tak" van Bedryfsingenieurswese is sekerlik van groot omvang, van diverse aard en diep gesetel. Verskeie historiese "helde" het betekenisvolle bydraes gemaak tot die ontwikkeling van die Bedryfsingenieurswesevakgebied. Ter wille van betoogvoering sal in hierdie artikel aanvaar word dat Bedryfsingenieurswese uit minstens twee identifiseerbare sub-vakgebiede bestaan naamlik : Die Determinisme en die Stogasme. 'n Poging word aangewend om die vroeë geskiedenis van die stogasme na te speur wat op sy beurt aaneengesnoer is met die geskiedenis van die waarskynlikheidsleer en statistiek en dus toevalspelle, dobbelary en wiggelary. Die lewenswyse, tydsgewrig, bydraes en persoonlikheidseienskappe van 'n aantal helde en skurke, kampioene en prulle van die stogastiese wêreld word kortliks bespreek, op 'n ietwat lighartige maar nie noodwendig ligsinnige wyse.

\footnotetext{
${ }^{1}$ History is by no means an exact science and is certainly subject to random and/or systematic errors, uncertainty, personal interpretation and opinion. Some of the "facts" contained in this paper may be apocryphal in nature and the truthfulness and accuracy of the information may at best be declared as "beyond a reasonable doubt".
} 


\section{INTRODUCTION}

An interest shown by a country, an organization or an individual in its own history and roots, is at least an indication that this entity may have reached some state of maturity in terms of culture and civilization. It is the author's contention that this state has been reached by the Industrial Engineering profession in South Africa. Whereas the mature Industrial Engineer may be interested in history for the sake of the lessons that may be learned in this way, the relatively immature individual may show interest mainly for the purpose of identifying idols, role models and heroes.

The "roots" of Industrial Engineering are certainly extensive, diverse and deep. Similarly, there are numerous historical "heroes" that made significant contributions to the development of the Industrial Engineering discipline. For the sake of argument, this paper will assume that Industrial Engineering has at least two identifiable main roots, namely Determinism and Stochastism (see figure 1). The deterministic root is mainly entrenched in the work of people such as Adam Smith (1723-1790), Charles Babbage (1791-1871), Frederick Winslow Taylor (1856-1915) and Frank Bunker Gilbreth (1868-1924). There are numerous other roots that may not easily be classified as either deterministic or stochastic, for example, the roots imbedded in the economic, management, engineering, human and natural sciences. However, this paper will attempt to trace the early history of the stochastic root which is very closely linked to the history of probability and statistics and hence games of chance, gambling and divinity.

The main purpose of the paper is to pay homage to some of the great mathematical and statistical minds of the past and to endeavour to infuse some life into what is so often considered by Industrial Engineers as the "dull subject of mathematical statistics". At the same time the paper will attempt to show that these great heroes were often just ordinary, "normal" human beings, but with private lives and specific personalities, which were sometimes quite interesting and even, entertaining. The discussion will be limited to individuals who were born, lived and worked in the period 1500 to $1900 \mathrm{AD}$.

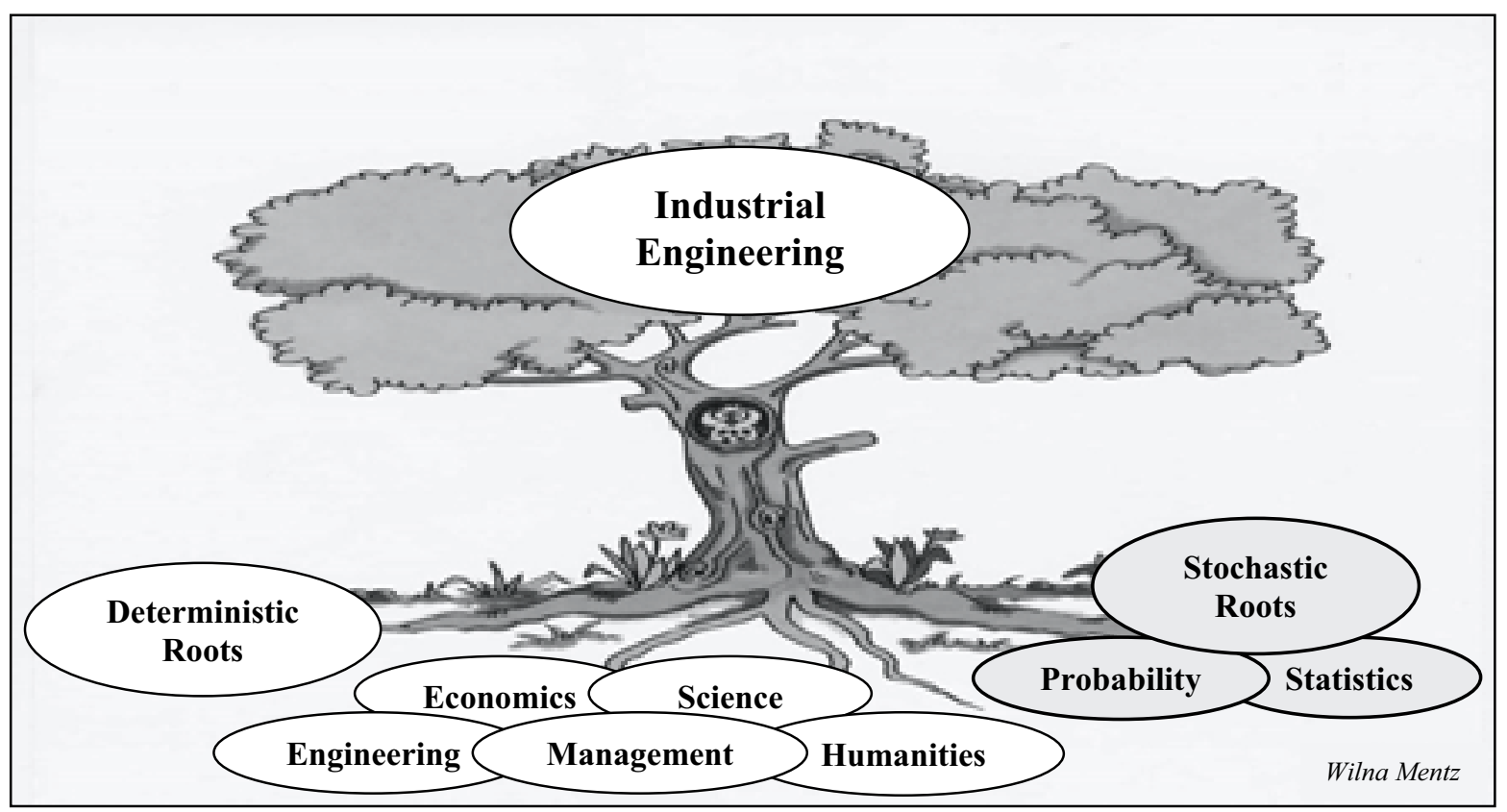

Figure 1: The Roots of Industrial Engineering 


\section{GIROLAMO CARDANO (1501 - 1576) : The Gambling Physician}

The ancient Britons, Greeks, Romans, Egyptians and the inhabitants of South America, the Middle and the Far East used astragali (knuckle bones), as a means for introducing unpredictability into games of chance (gambling), long before the birth of Christ. It was the Romans who imitated the astragalus by carving a rough cube from stone, wood or ivory and inscribing the sides with lewd figures and different numbers of dots thus creating the present day dice. These "random generators" were, and still are, used widely in a variety of games of chance but they were also used

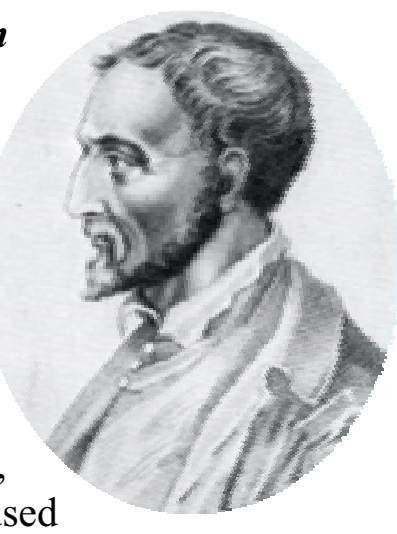
extensively in all kinds of religious ceremonies and specifically as a mechanism for soliciting

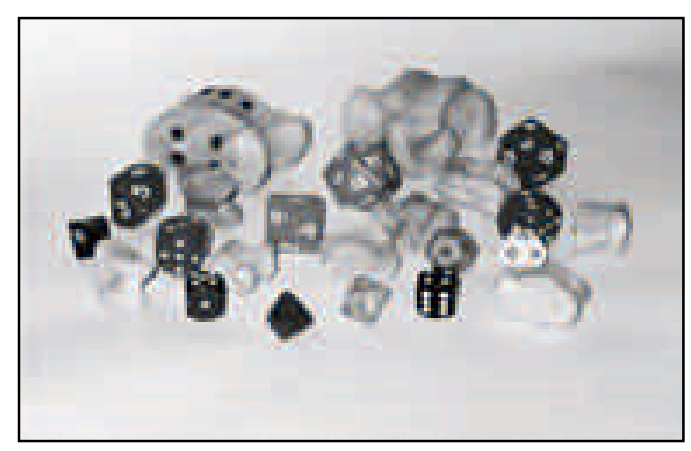

Figure 2: Astragali and modern dice the wishes of the gods (divination). The involvement of religion, and even magic, may be the restraining reason why no known attempt was made to mathematically analyse the stochastic process of throwing a die until the sixteenth century $^{2}$. It was left to the Italian from Pavia (or Milan), Girolamo Cardano, to show the audacity of suggesting that there may be some kind of logical structure in the seemingly unpredictable magic of a die.

Girolamo Cardano, the illegitimate son of Fazio Cardano, was a real rogue, lived a somewhat less than charming, certainly not a conservative, but nevertheless, a very colourful and interesting life. He had an unhappy childhood, but was gifted, and was appointed Professor of Medicine at Pavia in 1543, and at Bologna in 1562. In 1551 he treated the Archbishop of St Andrews in Scotland for an asthmatic complaint and in London cast the horoscope of Edward VI. His family life was tragic; his eldest son was executed for the murder of his wife, his other son was constantly jailed for various crimes and his daughter was a prostitute. The Inquisition arrested him for heresy, at the age of 69, since he dared to cast a horoscope of Jesus Christ (contained in De astrorum iudiciis)). He immediately recanted and was subsequently hired by Pope Pius V as an astrologer and later granted a pension by Pope Gregory XIII. He predicted the date of his own death by casting his own horoscope. However, since he was healthy at the end of the specified day, he poisoned himself! Quite a lot is known about Gardano since he wrote a lengthy autobiography, De propria vita (The book of my life). He was strongly disliked by some of his contemporaries and despised by some of his successors, while his biographers alternately described him as a charlatan and a persecuted savant. Some historians are even of the opinion that the contents of De propria vita are a complete hoax or at best a figment of Gardano's over active imagination. Cardano was a skinny man, with a long neck, a heavy lower lip, a wart over one eye, and a voice so loud that even his friends complained about it. He was a physician, philosopher, and engineer, a theoretical and applied mathematician, astrologer, eccentric, liar and gambler, but above all a gambler.

\footnotetext{
${ }^{2}$ A Latin poem, ascribed to Richard de Fournival (1200-1250), does contain a fairly accurate enumeration of the number of ways in which three dice may fall but does not contain any attempt at generalization or mathematical analysis.
} 
In his own words : "I have an immoderate devotion to table games and dice .... During many years .... I have played not off and on but, as I am ashamed to say, every day”.

He did not escape the consequences of his lifestyle : I suffer from diarrhoea, ruptures, kidney trouble, palpitations and even an infection of a nipple".

He was also fully aware of his own peculiar personality traits : "I am hot-tempered, singleminded, given to woman, cunning, crafty, sarcastic, diligent, impertinent, sad, treacherous, a magician and sorcerer, miserable, hateful, lascivious, obscene, lying, obsequious, and fond of the prattle of old men".

Nevertheless, he was the first scientist who made a serious attempt to analyse, mathematically, the probabilities inherent in the throwing of dice. He wrote 131 printed works on many subjects, including mathematics, astronomy, physics, urine, teeth, the life of the Virgin Mary, morality and immortality. He claimed to have burned 170 other manuscripts before publication and on his death he left another 111 manuscripts. Some of his most popular

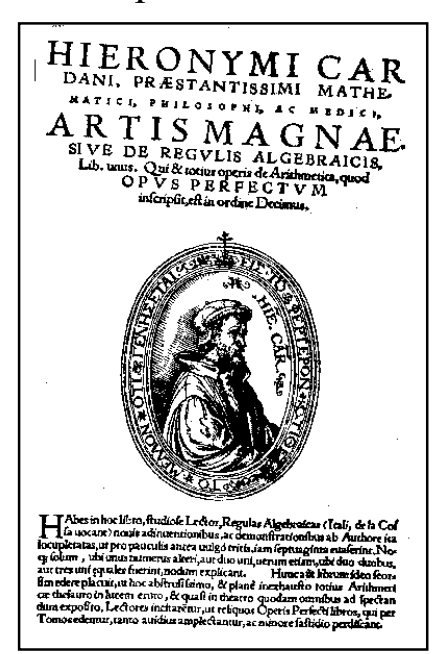

Figure 3: The title page from Ars Magna and best selling works include De Sibtilitate Rerum (On the Subtlety of Things), Ars Magna (The Great Art) and Liber de Ludo Aleae (Book on Games of Chance). However, it was his passion for gambling which probably motivated Cardano to apply his considerably mathematical skills to the analysis of dice throwing. He converted experimentation into theory, defined "An Honest Die", used the concept of mathematical combinations to calculate "Chance" (he never used the word probability), defined Equallyprobable Events and the concept of expressing Probability as a Fraction. The very early basis of modern probability theory, and thus the early stochastic roots of Industrial Engineering, should be seen as his lasting contribution. Once Cardano has broken the (d)ice, further development of the mathematics of chance followed relatively quickly with significant contributions made by most of the great mathematical minds of the time.

\section{GALILEO GALILEI (1564 - 1642) : The High and the Mighty}

Galileo considered the problem of playing dice (gambling) unworthy of serious mathematical consideration but was forced by his gambling employer, the Grand Duke of Tuscany, to write an essay, Sopra le Scoperty dei Dadi (On Playing Dice). To show his total disgust with the topic, Galileo wrote this essay in a vernacular Italian and not in the customary Latin. Nevertheless, it was the First Paper on Probability and the first time the word probabilità was used. He boldly advocated doctrines about the universe (for example the Copernican theory) that were condemned by the Pope and after a long and

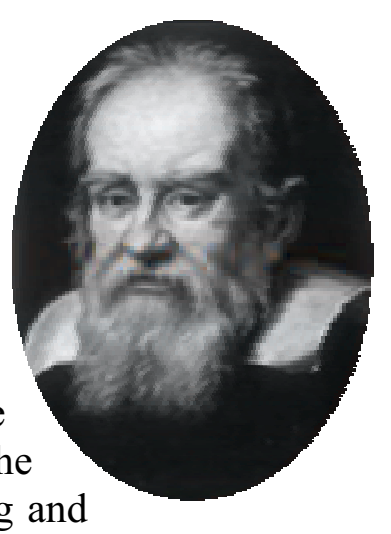
famous trial, he was "pronounced to be vehemently suspect of heresy", and condemned to life-imprisonment (commuted to life-long house arrest). A statement by the Pope before the Pontifical Academy of Sciences in 1992 may be interpreted as a rehabilitation of Galileo. 


\section{PIERRE (DE) FERMAT (1601 - 1665) : The Rich Lawyer}

Fermat was a successful and rich lawyer for whom mathematics was a sideline and something to be used to exercise and amuse his extraordinary mathematical genius. Most of his work was communicated by way of letters to his friends, often as theorems, statements or even puzzles without providing the proof, leaving most of it to Leonard Euler (1707-1783) a hundred years later. This was at least partly due to the fact that he experienced severe problems in publishing his work for the simple reason that he suffered from a total lack of, or disinterest in, editorial polish. Andrew Wiles, the British mathematician from Princeton, only recently (1993) proved the correctness of Ferma's, "Last Theorem". The correspondence between Fermat and Blaise Pascal is considered to mark the Foundations of Probability Theory, even though it was almost exclusively concerned with a gambling problem - The problem of how to divide the "pot" amongst the players when a gambling game is suspended.

\section{JOHN GRAUNT (1620 - 1674) : The Mortal Haberdasher}

Graunt was an opulent, influential merchant, businessman and haberdasher but with very little, if any, formal education and certainly not in science, mathematics or statistics. Nevertheless, he was elected as a fellow of The Royal Society in 1662 on the insistence of King Charles II who said ".... if they found any more such tradesmen, they should be sure to admit them all, without any further ado”. His house burned down during the Great Fire of London (1666), his business suffered severely and he died in poverty.

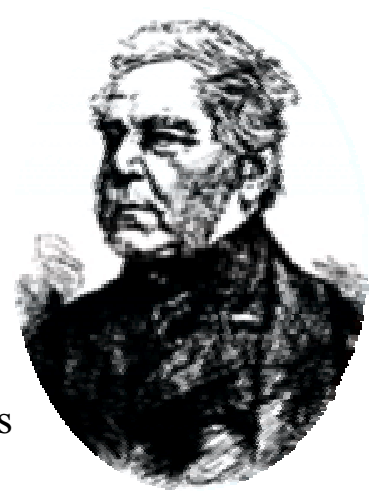

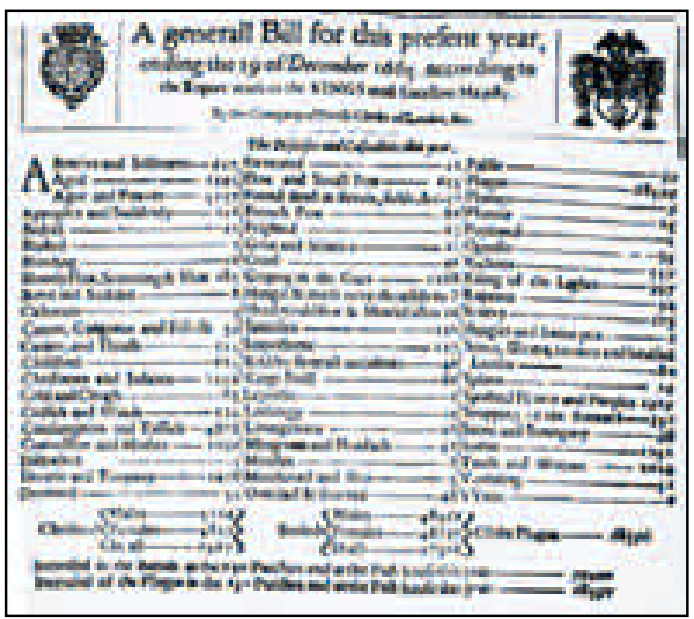

Figure 4: The Bill of Mortality for 1665
He was very much interested in the London "Bills of Mortality" and realised the possible value of such information for the profitable purpose of estimating the expected value of life annuities issued by the state and how such observed data may be used to investigate and possibly improve the social conditions in a country.

His publication in 1662, Natural and Political Observations ... made upon the Bills of Mortality, laid the foundations for Statistical Inference (inferring population estimates from a limited and incomplete data set). The word "Statistics" (the analysis of quantitative facts about the state) originated from this work, and he may be regarded as the founder of the modern day Actuarial Sciences as well as the science of Demography. He set up a table for "Average Life Expectancy" which is the basis for much of the life insurance industry and may be seen as the innovator of the concepts of Sampling Theory. Though he never used the word "probability" he did use words such as "hazard", "likelihood" and the most intriguing concept of "an even lay". 


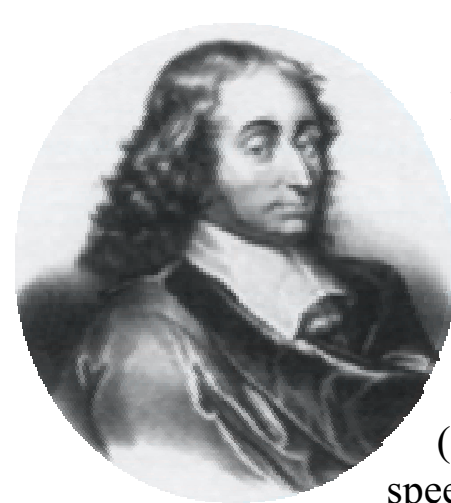

BLAISE PASCAL (1623 - 1662) : The Son of a Tax Farmer

Pascal was a child prodigy who was tutored in mathematics by his father while the Jansenists (a Catholic sect) worked on his soul. His father removed all the books on mathematics from the house (they were only returned when Pascal was twelve) thus only managing to intrigue the young Pascal. At the age of sixteen he wrote a paper on the mathematics of the cone that impressed even the great René Descartes (1596-1650). Soon afterwards (1642), Pascal developed a mechanical calculator, the Pascaline, to speed-up arithmetic calculations for his father and thus may have constructed the first computer. Chevalier de Méré, a nobleman with an insatiable appetite for gambling, solicited Pascal's help in "improving the odds in gambling". Pascal turned to Fermat for support and thus started an amazing journey of discovery into the Mathematics of Chance. Pascal was also a very religious man who, in his old age (he died at the age of 39), was convinced that the practice of mathematics was a mortal sin. Nevertheless, he could not refrain from bringing some mathematical logic to bear even on his religious writings as demonstrated by the so-called "Pascal's Wager" : "If God does not exist, one will loose nothing by believing in him, while if he does exist, one will lose everything by not believing. ... we are compelled to gamble!"

\section{CRISTIAAN HUYGENS (1629-1693): The Son of a Diplomatic Poet}

Huygens was the son of a poet who worked as a diplomat in the service of the Prince of Orange and suffered from persecution mania, specifically with regard to his family. His mathematical education was greatly influenced by Rene Descartes who was a friend of his father. He devised a new and better way of grinding and polishing lenses and using one of his own lenses, he detected the first moon of Saturn in 1655 and in 1657 he patented the first pendulum clock. In this way he contributed significantly to the development of the two most important tools required by any Industrial Engineer involved in work study; a stopwatch and a pair of binoculars !

In 1657 he wrote the very First Textbook on Probability Theory, De Ratiociniis in Ludo Aleae (Of reasoning on the play of dice), which made a significant impact and was read extremely widely. Even the great Sir Isaac Newton read and annotated his own copy of this book very carefully. In the final years of his life Huygens composed one of the earliest discussions of extraterrestrial life, published after his death as the Cosmotheoros (1698).

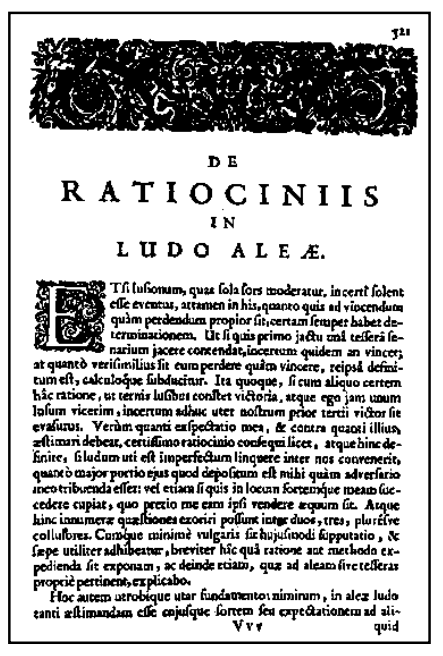

Figure 5:

The title page from

De Ratiociniis in Ludo Aleae 


\section{JACOB, JOHANN AND DANIEL BERNOULLI : The Fighting Brothers, Son and Nephew}

Nicolaus was the patriarch of this mostly quarrelsome and jealous family, consisting of a dynasty if highly gifted mathematicians and scientists, sometimes used by Sir Francis Galton as a good example to illustrate his concept of eugenics. Nicolaus' sons, Jacob (or Jacques, or James) (16541705), Nicolaus I, and Johann (or Jean or John) (1667-1748) and their numerous offspring, amongst others, Nicolaus II the Slow, Nicolaus III and Daniel (1700-1782), made a variety of valuable contributions.

Jacob defined the concept of "moral certainty", thus creating the basis for Statistical Inference. He formulated the Law of Large Numbers and illustrated it with his "Jar of Pebbles". His Ars Conjectandi was published posthumously in 1713, contributing significantly to the principles of Sampling Theory and Quality Control

Johann had long lasting and major disputes with his brother Jacob, his son Daniel, de l'Hôpital, the Church, the Governors of his University and even became involved in the Newton-Leibniz controversy. In 1734 he shared a prize with his son Daniel, with the result that the jealous father banned his son from his house ! He even tried to pre-date the manuscript of his book Hydraulica in an attempt to obtain priority over his own son!

Daniel may be seen as the father of Risk Analysis and Utility Theory,

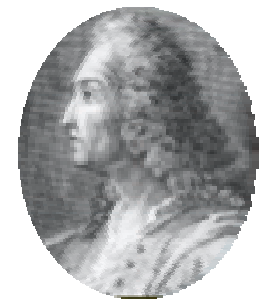

Jacob

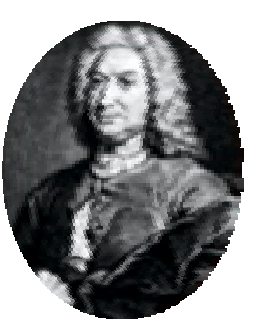

Johann

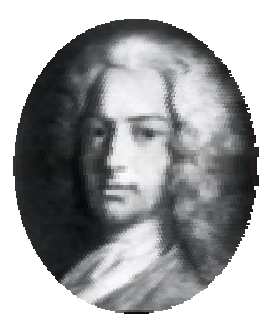

Daniel though "drawing of lots" caused him to fail in obtaining academic appointments at least three times !

\section{ABRAHAM DE MOIVRE (1667 - 1754) : The Persecuted Huguenot}

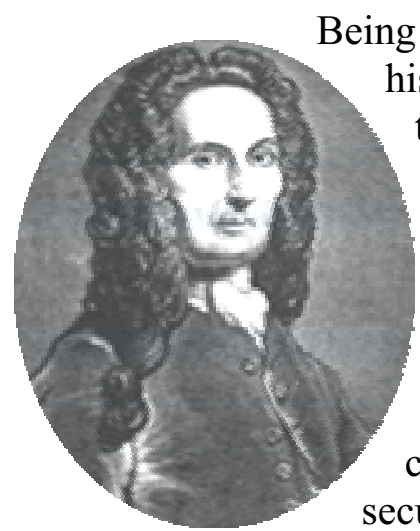

Being a French Huguenot, de Moivre was imprisoned for over two years for his religious beliefs. He managed to flee to England, never to return to the hated country of his birth and he never, ever, wrote anything in French, except a few forlorn love letters. De Moivre was a disgruntled man who never managed to get the academic position he craved, and deserved. (He experienced the misfortune of being a Protestant in a Catholic France, and even worse, a Frenchman in an England where appointing a Frenchman to an academic position was out of the question). He acted as a consultant to gamblers, tutored the children of the rich and worked on the mathematics of annuities, never securing a full-time paid position and he died in abject poverty. Similar to Gardano, he predicted his own death; this time by using an arithmetic progression of his sleep patterns and he actually died on the predicted day!

He published The Doctrine of Chance in 1718 and derived the Normal Distribution as an approximation to the binomial distribution in 1733, long before the birth of either Gauss or Laplace ! Apart from this, his greatest contributions are probably the concept of Expected Value and the definition of the Standard Deviation as a measure of dispersion. (Coining of the word "standard deviation" had to wait for Karl Pearson). 


\section{THOMAS BAYES (1702 - 1761) : The Dissenting, Non-Conformist Minister}

Bayes' father was one of the first non-conformist ministers and this may have been the reason why the young Thomas was privately tutored. There exists the intriguing possibility that one of his tutors may have been Abraham de Moivre. However, Bayes followed in his father's footsteps and became a Presbyterian minister. He preferred to practice mathematics in the privacy of his study and his only publication, Essay towards solving a problem in the doctrine of chances, was published (1763) posthumously on his own instructions. Though it started a major controversy, raging for many years, it nevertheless made major contributions to the science of Decision Analysis and what is today

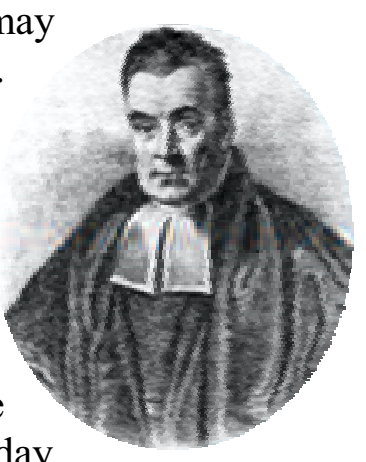
known as Bayesian Inference. Recently (1999) some doubts were raised as to whether Bayes was the first to formulate Bayes' Theorem !

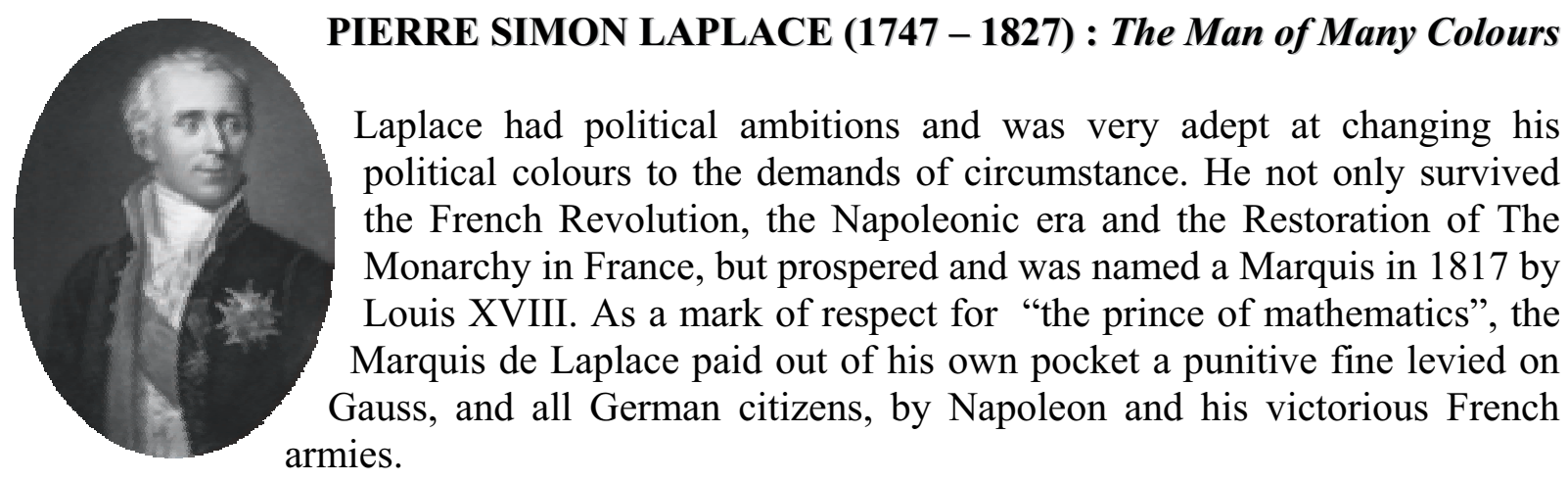

His Thèory Analytique des Probabilités was published in 1812 and included discussions on the probability of compound events, Buffon's needle, mathematical expectation and probabilistic views on legal matters, life expectancy and the length of marriages. The development of the Central Limit Theorem may be attributed to him and he warned against "the tendency to assign a particular cause to an outcome when in fact only the laws of probability are at work" !

\section{CARL FRIEDRICH GAUSS (1777 - 1855) : The Paranoiac Recluse}

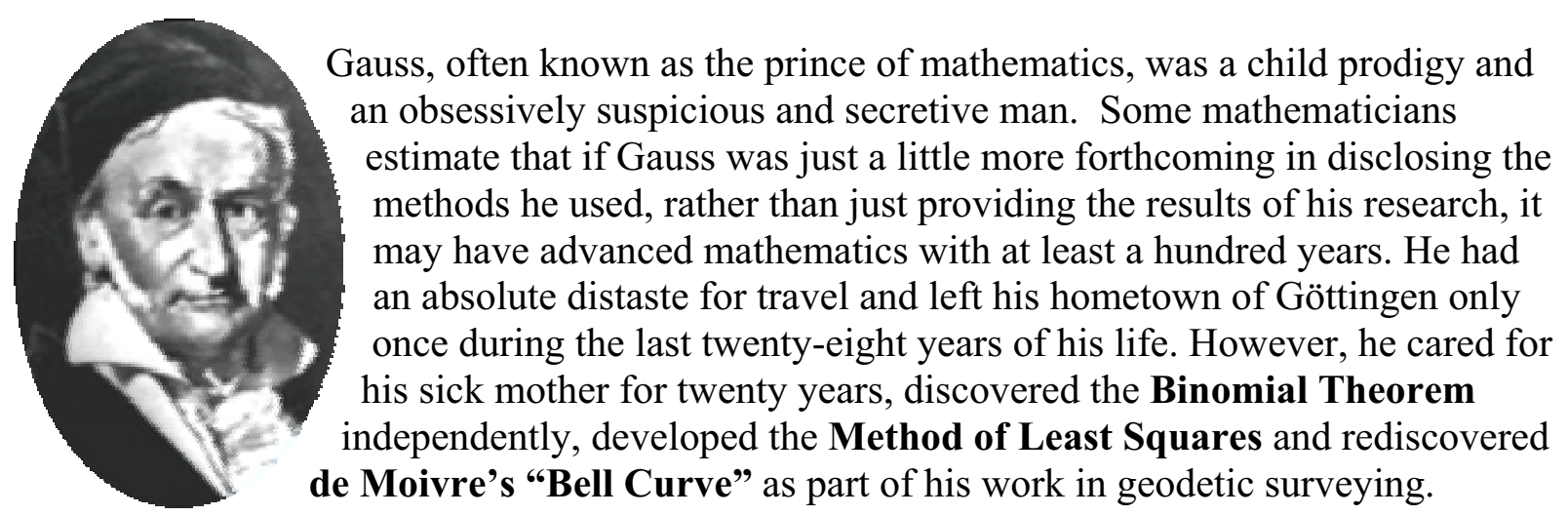




\section{FRANCIS GALTON (1822 - 1911) : The Gentleman Explorer}

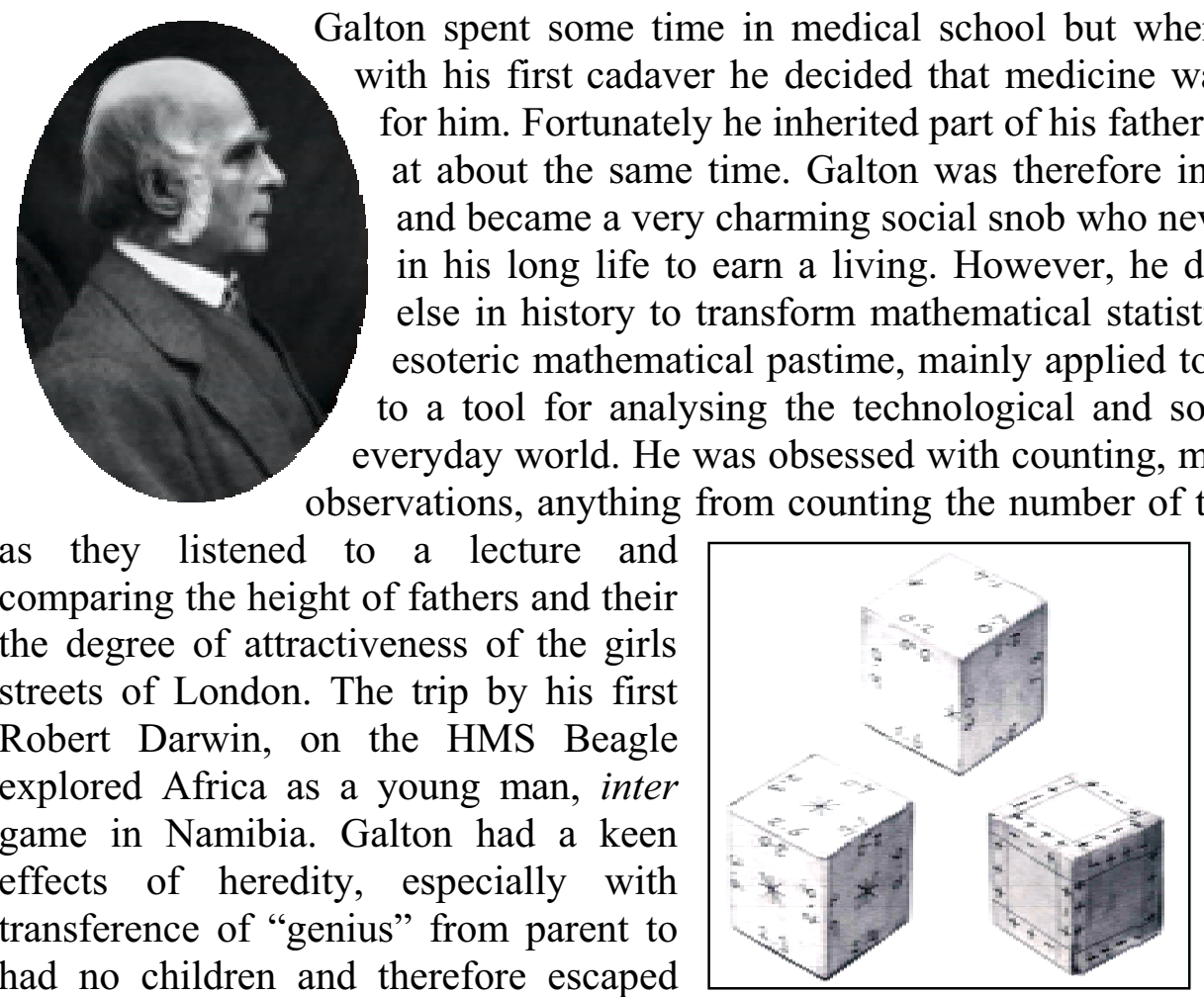
seeing his own offspring possibly not pet theories. He suffered from
Figure 6: Galton's dice severe depression and under these circumstances referred to himself as "the man with the sprained brain".

Galton developed a set of dice for the generation of standard normal variates thus laying some of the foundations for Simulation Modelling. He devised the basis of all modern weather maps and discovered the uniqueness of human fingerprints. He saw "bell curves" wherever he

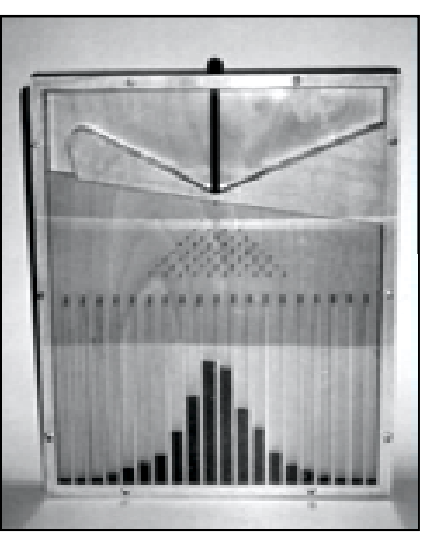

Figure 7: Quincunx I went and was principally responsible for the transformation of the Normal Distribution (he coined the word "normal") from being a "Law of Error" used mainly in astronomy to a "Law of Nature" applicable to almost every facet of everyday life. With his gadgets, the Quincunx I and II, he demonstrated, and to some extend proved, the tendency towards "normality" in nature. Together with Quetelet, Edgeworth and Pearson he brought mathematical statistics into the realm of the social sciences and invented the concept of Correlation. He insisted that variety is ever present but that there is often order in what may seem chaos and sometimes there is at least some structure in the seemingly unpredictability of random events.

Using his Quincunx, some experiments with peas and what may only be described as an astonishing brilliant "mind experiment", Galton discovered and formulated the phenomenon known as "Regression to the Mean" or, according to the title of the relevant publication, 
Regression towards Mediocrity in Hereditary Stature. The importance of this concept to humankind, may be ranked at the same level as Darwin's Theory of Evolution, Newton's Laws of Gravity and Einstein's Theory of Relativity!

\section{CONCLUSION}

This paper discussed only a few of the most important (in the author's opinion) "heroes" of the stochastic "root" of Industrial Engineering, from Cardano and his gambling mania to Galton and his "normal" dice. Numerous other individuals, from the period 1500 to 1900 AD, also made significant contributions, for example :

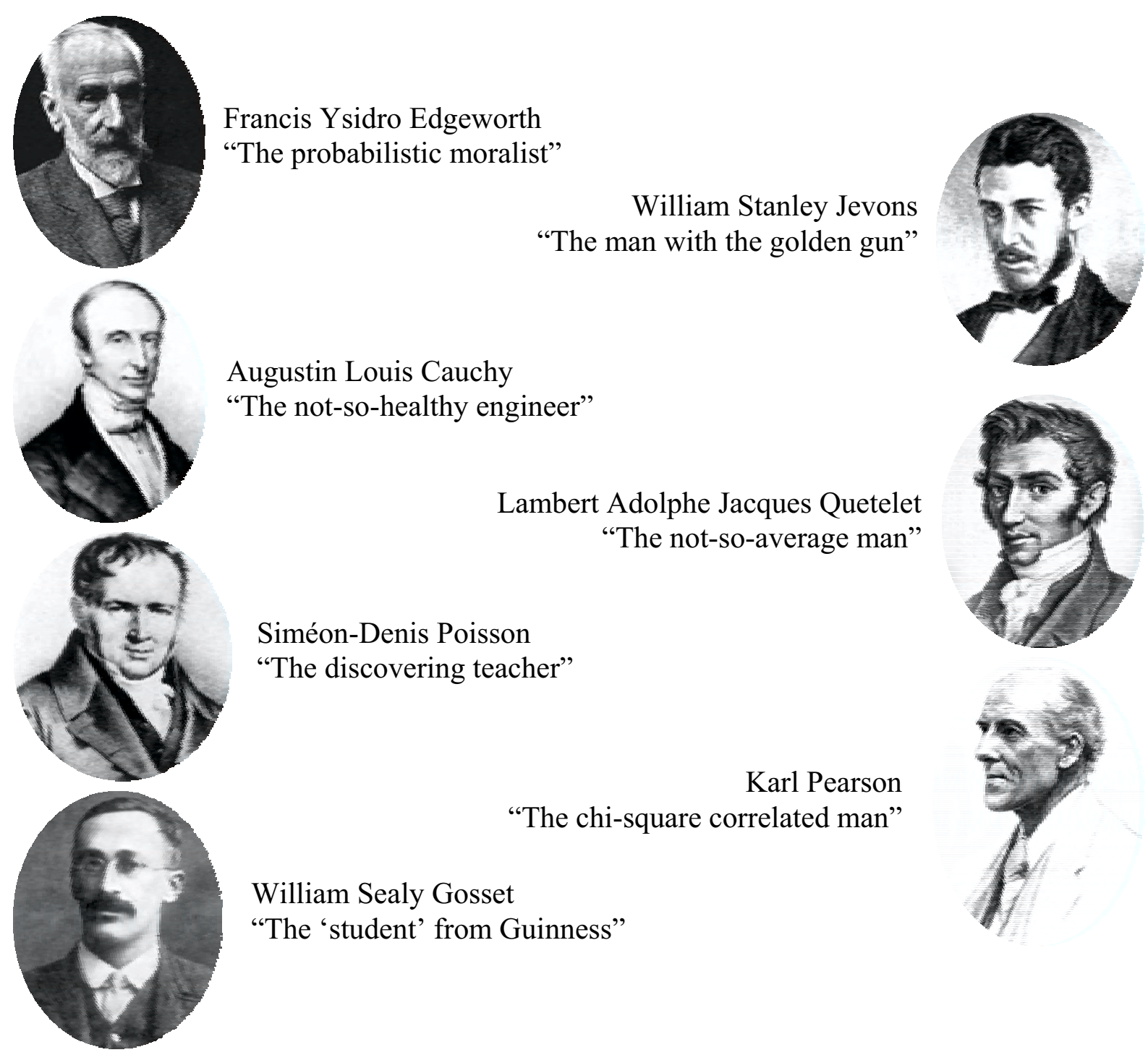

Without the contributions of these individuals a significant and valuable part of Industrial Engineering would probably not be in existence today. 
Due credit and recognition is hereby given to the sources of all the pictures used in this paper. These images were obtained mainly from sources $16,17,18$ and 19.

\section{SOURCES (FOR FURTHER READING)}

[1] Bernstein P L, 1996, Against the Gods : The Remarkable Story of Risk, John Wiley and Sons.

[2] Boyle D, 2000, The Tyranny of Numbers : Why Counting can't make us Happy, Harper Collins Publishers.

[3] David F N, 1962, Games, Gods and Gambling, Hafner Publishing Company.

[4] David H A and Edwards A W F, 2001, Annotated Readings in the History of Statistics, Springer-Verlag.

[5] Devlin K, 1998, Life by the Numbers, John Wiley and Sons.

[6] Gleick J, 1988, Chaos : The Amazing Science of the Unpredictable, Vintage.

[7] Hald A, 1990, A History of Probability and Statistics and their Applications before 1750, John Wiley and Sons.

[8] Kendall M and Plackett R L, 1977, Studies in the History of Statistics and Probability, Volumes I and II, Charles Griffen and Company.

[9] Magnusson M (editor), 1990, Chambers Biographical Dictionary, Fifth edition, W and R Chambers.

[10] Mankiewicz R, 2000, The Story of Mathematics, Cassell and Company.

[11] Stewart I, 1989, Does God Play Dice? : The New Mathematics of Chaos, Second edition, Penguin Books.

[12] Stewart I, 1995, Nature's Numbers : Discovering Order and Pattern in the Universe, Weidenfeld and Nicolson.

[13] Stigler S M, 1999, Statistics on the Table : The History of Statistical Concepts and Methods, Harvard University Press.

[14] Tal J, 2001, Reading between the Numbers : Statistical Thinking in Everyday Life, McGraw-Hill.

[16] http://www-history.mcs.st-and.ac.uk

[17] http://www.york.ac.uk/depts/maths/histstat

[18] Microsoft Encarta 2001, Software edition.

[19] Encyclopaedia Britannica 2002, Software edition 